\title{
Conflict and Team Atmosphere in Teams Engaged in Outsourcing
}

\author{
H. Carr Osborn \\ College of Engineering and Computing \\ Nova Southeastern University \\ carr.osborn@live.com
}

\author{
Souren Paul \\ College of Engineering and Computing \\ Nova Southeastern University \\ souren.paul@gmail.com
}

\begin{abstract}
Outsourcing is a prevalent arrangement for leveraging resources and knowledge. However, outsourcing improperly managed can undercut any benefits gained. Outsourcing tends to relate to team atmosphere. This is also true for both task and relationship conflict. As team compositions evolve, tasks become more complex, and inter-company relationships progress, it is increasingly important to understand how these changes affect team performance. We conducted a survey to collect data for our study. We find that team atmosphere is positively related to team performance. We also find that team conflict has negative relationship with team atmosphere.
\end{abstract}

\section{Introduction}

Team performance, and what affects it, has been a widely-studied topic. Investigations on the effects of team spirit, continuity, cohesion, satisfaction, and information sharing on team performance are a small sampling of the factors that have been examined [5, 32]. Team characteristics have been studied individually and in combination. Team characteristics have been grouped, regrouped, and refined to define team atmosphere $[23,45,53]$. Just as team atmosphere has been widely researched, so has conflict.

Team conflict can arise from relationship or task issues. Relationship conflicts are concerned with the differences in personal taste, political preference, values and ideology, whereas task conflicts relate to the disagreements on the distribution of resources, about procedures and policies, and about judgments and interpretation of facts [10]. Task conflict, has been studied in depth in both traditional teams [10, 25] and virtual teams $[39,40]$. Additionally, research has been conducted on the relationship between conflict and team performance $[15,41,45]$. Research of task conflict on team performance has mixed results. Relationship conflict studies, on the other hand, have more consistently revealed the negative association it has with team atmosphere and performance. The impact on team performance can be exacerbated when coupled with complex tasks.

We extend the prior studies on team atmosphere to examine its influence on team performance. In addition, we attempt to examine if team atmosphere is related to team conflict.

We used the data, collected through an initial survey to assess our conjectures. We find that team performance is positively related to team atmosphere. We also find that team conflict has negative relationship with team atmosphere.

We review the extant literature on the core constructs of our study and develop our conjectures in the next section of the paper. Next, we discuss the research method, which is followed by the presentation of the results. We end the paper with a discussion on the findings, the limitations of our study, and the conclusion.

\section{Literature review and model development}

As illustrated in following sections, we anticipate that team atmosphere to be negatively associated with both task and relationship conflict. However, better strategic alignment of outsourcing will be positively associated with team atmosphere. Greater task complexity will relate negatively to team performance, as will relationship conflict. Team atmosphere will relate positively to team performance. Task conflict's association with team performance will be positive.

\subsection{Team performance}

Kirkman, Rosen, Tesluk and Gibson [27] posited that performance could be divided in to the two groups of team empowerment and satisfaction. Team empowerment referred to the team's ability to function autonomously, to be proactive, and engage in process improvement. Outcome can be defined in several ways. Among them are, innovativeness, comparison to archived measures, and customer satisfaction. 
Algesheimer, Dholakia and Gurău [1] divided performance in to the categories of subjective and objective. Subjective refers to what was expected whereas, objective was the actual performance. Subjective elements include the perception of performance and satisfaction. Both categories can be measured from within the team and from the perspective of the customer. The customer's perceptions are generally tied to the more tangible, or objective, dimensions of the timeliness and quality of the team's output. However, the team's perception can be related to internal factors such as, conflict, conflict management, and effective leadership. [6, 41]

The definition used here for team performance was based on a construct developed by Ancona and Caldwell [2]. It measured output, efficiency, and timeliness. Output is the volume and quality of the product of the team. Efficiency refers to the elegance of the process. Timeliness measures the team's ability to meet deadlines.

\subsection{Team atmosphere}

Team atmosphere has long been connected to team performance. Edmondson [12] investigated the positive relationship between psychological safety, trust, and respect with team performance. Jehn and Mannix [23] cited trust and respect along with cohesiveness, conflict discussions, and liking other team members as the items that comprised team atmosphere. In 2010, Jehn, Rispens and Thatcher [24] dropped conflict, discussions, and liking from their construct. Also, they replaced cohesiveness with commitment.

Trust and respect have been referred to as a psychologically safe state or space [12]. Trust is essential in creating a healthy environment. Trust in this environment allows a free exchange of ideas without the fear of losing position or esteem.

Commitment is considered a key part of trust in groups [48]. Commitment at the individual level can be particularly challenging to establish and maintain in virtual teams. In virtual teams, team leaders need to consciously work to compensate for the spontaneity that is often lacking in dispersed teams [7]. Additionally, there is the expectation of reciprocal commitment [7]. This is the idea that the individual's commitment to the group will be met with commitment from the other participants. Mutual commitment can also pave the way for respect.

A supportive environment and openness to hear others ideas are considered forms of respect [48]. Zarraga and Bonache [53] referred to it as leniency in judgment. The idea is that team members would allow differing opinions without dismissing them before careful consideration. Respect is also a contributor to confidence with in the team. This confidence allows team members to speak up without fear of rejection or embarrassment [12].

Like respect, team cohesion is an essential element in aiding team performance [26]. Team cohesion is a social dimension used to measure the interpersonal interactions. Cohesion has a positive effect on individual performance [50] and team satisfaction [43]. In a highly competitive environment, cohesion can offer the needed advantage [44].

The relationship between trust and team performance has been well documented. Like trust, commitment is a necessary element of team atmosphere for team performance. In virtual teams, commitment often takes time to develop. Maznevski and Chudoba [31] associated commitment with decision quality, an important element of team performance.

This study used the Jehn, Rispens and Thatcher [24] definition of team atmosphere. They defined team atmosphere as trust, respect and commitment. Trust creates a safe space for taking risks. Respect is the openness to other's opinions and ideas. Commitment is the level of engagement or buy-in with the team.

Perceptions of disrespect can be detrimental to commitment and trust [47]. When a team member's opinion or suggestion is not given due consideration, it can cause a feeling that their ideas are less valid than others. This can lead to a sensation of disrespect. Respect, or the perceived lack of it, can affect a team member's effort. This combined with the documented effects of trust and commitment on team performance indicate that there is a direct association between team atmosphere and team performance. Hence, the first conjecture is:

$\mathrm{C} 1$ : There is a positive relationship between team atmosphere and team performance.

\subsection{Intra-group conflict}

In addition to the association of team atmosphere with team performance, conflict and performance in the traditional face-to-face team have a long history of examination. Jehn [21] is considered the seminal work on task conflict. More recent submissions include Kostopoulos and Bozionelos [29] and Bradley, Postlethwaite, Klotz, Hamdani and Brown [4].

Conflict falls into the three broad categories of process, relationship, and task. Process conflict is based on discrepant views on how resources should be allocated and who should perform team activities. Whereas relationship conflict stems from personal incompatibilities [21]. Task conflict is differences in 
perceptions on approach, execution, and expected outcomes of tasks.

Early on, researchers considered all conflict to have a negative impact on team performance [11]. In the 1990s however, evidence began to surface that indicated some conflict was beneficial [21]. Pazos [41] demonstrated the positive relationship between task conflict and team performance.

Not all research supports the beneficial effect of task conflict on team performance. Gallenkamp, Riedl, Korsgaard, Picot, Welpe and Wigand [15] found no impact of task conflict on team output. De Dreu and Weingart [10] suggested the conflict, no matter the type, had a negative impact on team performance. Shaw, Zhu, Duffy, Scott, Shih and Susanto [45] indicated that, if relationship conflict was low, the effect of task conflict on team performance was an inverted U. Some task conflict was beneficial. Too much task conflict had a detrimental effect on team performance. This supported the results of earlier work by De Dreu [9], and Paul and Ray [38]. Task conflict in moderation could be beneficial to team output.

Our definition of task conflict leveraged that of Hinds and Mortensen [19]. For task conflict they focused on the number times there was disagreement on how to perform a task. Additionally they examined the significance of the differences.

Trust, respect and commitment are key dimensions of team atmosphere [24]. Both trust and commitment can play a role in managing task conflict. This is especially true in outsourced arrangements. A lack of either these dimensions can cause behavior to appear opportunistic. This can lead to increased conflict [48]. Likewise, task conflict can reduce trust and respect. Hence the conjecture:

$\mathrm{C} 2$ : Task conflict is related negatively with team atmosphere.

Task conflict can positively influence performance when the conflict is seen as a challenge rather than a threat [25]. In addition, the timing of the task conflict can also impact its effect on team performance. Task conflict occurring half way through the work actually improved performance [23]. Hence the conjecture:

C3: Task conflict will have a positive relationship with team performance.

Our definition of relationship conflict was based on Jehn [22]. They defined relationship conflict in terms of emotional tension and anger. Interpersonal friction was also factored into the construct.
There is a long history in literature documenting the ill effects of relationship conflict $[13,22,46]$. Poor decision quality has been attributed to relationship conflict. This is because when relationship conflict is high, team members' attention is diverted to each other rather than on the tasks at hand. This limits the ability to process information and, in turn, leads to poor decision quality. Hence the conjecture:

C4: Relationship conflict will have a negative relationship with to team performance.

In addition to decreased performance, relationship conflict can also have other detrimental influences. Increased stress can reduce commitment to the team [22]. Relationship conflict can encourage animosity and hostile behavior [20]. Animosity and hostility are counterproductive for creating an atmosphere of trust and respect. Commitment, trust and respect are essential elements of the team atmosphere. Hence the conjecture:

C5: Relationship conflict will have a negative association with team atmosphere.

\subsection{Task Complexity}

Not all tasks are created equal. Two of the task characteristics Goodhue [17] identified were variety and interdependence. The greater the variety and interdependence the task, the more complex is the task. Independence is the degree to which a task is reliant on multiple teams, departments, or other resources. Coordination is critical to performance of highly interdependent tasks [49]. Two methods for mitigating interdependence are modularization and information sharing $[30,51]$. Modularization involves restructuring the work to minimize the interdependence. Whereas, information sharing proposes that coordinated communication can reduce the negative impact of interdependent tasks. Information sharing, when combined with offshoring or remotely located teams, can prove challenging and require a significant investment $[3,36]$.

Task complexity, as it was used here, was defined by Goodhue [17]. They defined task complexity through ambiguity and interdependence. Ambiguity refers to the clarity of the problem. Is this a variation on previous work at or 'new territory' for the team? Interdependence examines the level of cooperation or coordination with external resources.

Routineness can be viewed as the lack of variety. Repeatable and routine tasks tend to be more stable and have lower frequency of problems [30, 42]. 
Conversely, non-routine tasks encounter problems to a greater degree [8]. Hence the conjecture:

C6: Task complexity is related negatively with team performance.

\subsection{Strategic alignment of outsourcing}

Increasingly, offshore outsourcing solutions are being applied in organizations. IT outsourcing can not only make good economic sense, it can also be a good strategic move. In some cases it is required for competitive advantage [37]. When structured correctly, outsourcing can provide flexibility and fluidity in both managing the size of the workforce and the expertise required [18]. This can be critical in volatile or rapidly changing markets.

Kishore, Rao, Nam, Rajagopalan and Chaudhury [28] split outsourcing relationships into the four categories of support, reliance, alignment, and alliance. They referred to this as the FORT model (four outsourcing relationship types). These categories are determined by the strategic impact and the level to which the relationship substitutes or displaces resources. Each of these outsourcing arrangement types has a distinct relationship with the contracting company. Support relationships are the traditional vendor services type of support. They do not have a strategic impact nor is there a significant amount of resource substitution with the outsourcing vendor. Reliance relationships are like support but they involve a deeper commitment from both parties and are generally for longer periods of time. A reliance relationship has a greater number of resources outsourced to the vendor but the strategic impact is still minimal to moderate. Alignment relationships tend to be project based. The resource displacement is not significant but the strategic impact on the organization is. Alliance relationships are more a joint venture than partnerships. Alliances displace employees and have a strategic impact on the organization. Additionally, outsourcing relationships tend to evolve or progress over time from one type to another [33].

When outsourcing is combined with downsizing, it can have a detrimental effect on morale. This can have a negative impact on productivity and performance [52]. If not managed correctly, downsizing can undermine any benefits gain through the outsourcing.

One source of conflict in teams containing outsourced members is competing underlying goals. For example, outsourcing expenses for the client are revenue streams for the vendor. This can cause each side to approach tasks differently. These disparate approaches and lead to task conflict.

Nam, Rajagopalan, Raghav Rao and Chaudhury [34] defined strategic alignment of outsourcing as the substitution of internal resources by vendor resources and the strategic impact of the relationship. This is the definition we used for this study. Resources included personnel, facilities, and equipment.

Strategically aligned outsourcing arrangements tend to support complex projects that may also have more uncertainty. The relationship tends to be more mutually beneficial. The benefit extends beyond the financial arrangement. This can promote joint problem solving. With an increased investment in the outcome of the team, there is a greater propensity to offer alternate opinions on tasks and their execution. Hence the conjecture:

C7: Strategic alignment of outsourcing is related positively to team atmosphere.

\section{Research methodology}

We conducted a survey to gather the necessary data to test the conjectures. The participants were from a cross section of industries, such as retail, finance, manufacturing, and technology. Information was gathered via an online survey designed for this study. The survey utilized SurveyMonkey $\AA$ to collect the data. This research was an exploratory survey. It was an attempt to validate the conjectures set forth in the previous sections [14].

\subsection{Research setting}

Participants for this study were recruited through the researchers' known contacts on the LinkedIn ${ }^{\circledR}$ networking site. The sample consists of individuals who are currently or were recently members of one or more teams. The unit of analysis was the individual team member. The goal of this was not necessarily to engage entire teams or even both sides of the same outsourcing contract. The individual responses were used to understand the relationships between the constructs.

\subsection{Instrumentation and the operationali- zation of variables}

Each construct of our study was operationalized using previously developed and validated measures. To the extent possible, this study measured indicators rather than perceptions. Constructs were adapted as needed to fit this format. Whenever possible, the 
variables for each construct utilized a seven-point Likert scale.

Team performance was measured by output, efficiency, and timeliness These variables were adapted from the Ancona and Caldwell [2] construct. Variables included the volume and quality of the team output, efficient use of time and resources, and the team's ability to meet deadlines.

Team atmosphere was from the vantage point of the individual. Based on the construct by Jehn, Rispens and Thatcher [24], team atmosphere measured the perception of trust, respect and commitment. Statements included "I like the other team members.", "The team can count on me", and "I respect the other team members".

The measure for task conflict was based on research by Hinds and Mortensen [19]. This construct measured the amount of conflict, regarding ideas, work, and opinions. A sample statement for this construct was "There is disagreement on how to perform tasks."

Strategic alignment of outsourcing measured the substitution of vendor resources for internal resources and the strategic impact of the relationship [34]. For purposes of this study, the construct developed by Goo, Kishore, Nam, Rao and Song [16] was adapted. A sample question was "Physical facilities/equipment have been procured and/or dedicated specifically to support the outsourced members of the team."

The construct for relationship conflict was derived from Jehn [22]. Statements included "There is emotional tension in my team.", "People often get angry while working in my team.", and "There is interpersonal friction in my team."

Finally, task complexity was based on the research by Goodhue [17]. These statements measured task ambiguity and interdependence. Statements included were "My team frequently deals with illdefined business problems.", "Frequently the business problems my team works on involve answering questions that have never been asked in quite that form before.", and "The business problems my team deals with frequently involve more than one business function."

\section{Results}

\subsection{Reliability and validity}

Table 1. contains the reliability and validity statistics of the constructs of our study. Per Nunnally [35], the acceptable construct reliability should be no less than 0.70 . All constructs fall comfortably above that. The lowest $\alpha$ was for task complexity at 0.734 .
The highest $\alpha$ was for team atmosphere at 0.958 . No changes to the indicators were made nor were indicators dropped to meet the test. The load patterns ranged from a low of 0.773 for task complexity to a high of 0.919 for team atmosphere.

Table 1. Convergent validity test

\begin{tabular}{|l|c|c|}
\hline \multicolumn{1}{|c|}{ Constructs } & $\begin{array}{c}\text { Construct } \\
\text { reliability a }\end{array}$ & $\begin{array}{c}\text { Load } \\
\text { pattern } \\
\text { range }\end{array}$ \\
\hline $\begin{array}{l}\text { Team performance } \\
\text { (with 5 indicator } \\
\text { items) }\end{array}$ & 0.899 & $\begin{array}{c}0.783- \\
0.887\end{array}$ \\
\hline $\begin{array}{l}\text { Team atmosphere } \\
\text { (with 8 indicator } \\
\text { items) }\end{array}$ & 0.958 & $\begin{array}{c}0.800- \\
0.919\end{array}$ \\
\hline $\begin{array}{l}\text { Task conflict (with } \\
3 \text { indicator items) }\end{array}$ & 0.853 & $\begin{array}{c}0.811- \\
0.872\end{array}$ \\
\hline $\begin{array}{l}\text { Relationship } \\
\text { conflict (with 4 } \\
\text { indicator items) }\end{array}$ & 0.888 & $\begin{array}{c}0.781- \\
0.905\end{array}$ \\
\hline $\begin{array}{l}\text { Task complexity } \\
\text { (with 3 indicator } \\
\text { items) }\end{array}$ & 0.734 & $0.773-$ \\
\hline $\begin{array}{l}\text { Outsourcing (with 3 } \\
\text { indicator items) }\end{array}$ & 0.848 & 0.836 \\
\hline $\begin{array}{l}\text { Construct reliability is estimated using Cronbach's } \\
\text { a coefficients. }\end{array}$ \\
\hline
\end{tabular}

\subsection{Testing Relationships}

The conjectures were tested using regression analyses. The level of significance was 0.05 . Results in the range of 0.05 and 0.10 were considered to suggest the nature of the relationship between the constructs. SAS software was for the analyses.

Table 2. Results of regression analysis for team atmosphere

\begin{tabular}{|l|l|}
\hline Independent variable & \multicolumn{1}{|c|}{ Team atmosphere } \\
\hline Intercept & $58.502 * * * *$ \\
\hline Relationship conflict & $-0.524 * * *$ \\
\hline Task conflict & $-0.51608 * *$ \\
\hline Outsourcing & $0.164 *$ \\
\hline R-Square & 0.4288 \\
\hline F & 30.03 \\
\hline Prob. (F) & $<.0001$ \\
\hline $\mathrm{N}$ & 117 \\
\hline & $\mathrm{C} 2=$ Yes \\
Conjecture supported $?$ & $\mathrm{C} 5=$ Yes \\
& $\mathrm{C} 7=\mathrm{Weak}$ \\
\hline$* \mathrm{p}<0.10 ; * * \mathrm{p}<0.05 ; * * * \mathrm{p}<0.01 ; * * * \mathrm{p}<0.001$ \\
\hline
\end{tabular}


Team atmosphere was examined first. Team Atmosphere was regressed on task conflict, relationship conflict, and strategic alignment of outsourcing. The results are presented in Table 2 . Conjectures 2 and 5 were supported. Also, there was weak support for conjecture 7.

Next, team performance was regressed on team atmosphere, relationship conflict, and task conflict. As Table 3. demonstrates conjectures 1 and 6 were supported. Conjectures 3 had weak support in our study. We did not find any support for conjecture 4 .

Table 3. Results of regression analysis for team performance

\begin{tabular}{|l|l|}
\hline Independent variable & \multicolumn{1}{|c|}{ Team performance } \\
\hline Intercept & 5.181 \\
\hline Team Atmosphere & $0.478 * * * *$ \\
\hline Relationship conflict & -0.17098 \\
\hline Task conflict & $0.230 *$ \\
\hline Task complexity & $-0168 * *$ \\
\hline R-Square & 0.5804 \\
\hline $\mathrm{F}$ & 40.76 \\
\hline Prob. $(\mathrm{F})$ & $<.0001$ \\
\hline $\mathrm{N}$ & 116 \\
\hline & $\mathrm{C} 1=\mathrm{Yes}$ \\
& $\mathrm{C} 3=\mathrm{Weak}$ \\
Conjecture supported? & $\mathrm{C} 4=\mathrm{No}$ \\
& $\mathrm{C} 6=\mathrm{Yes}$ \\
\hline$* \mathrm{p}<0.10 ; * * \mathrm{p}<0.05 ; * * * \mathrm{p}<0.01 ; * * * \mathrm{p}<0.001$ \\
\hline
\end{tabular}

\section{Discussion}

In this study, we focused on the teams that are engaged in outsourcing and examined the relationships between team atmosphere and team performance. In addition, we assessed how these constructs were related to team conflict and strategic alignment of outsourcing. We find that that team atmosphere is related positively with team performance. This supports the findings for the previous research $[31,43,50]$. In addition, we find that task complexity has a negative relationship with team performance. This confirmed prior findings on task complexity $[8,30]$. We also find that team conflict (both relationship and task) has a negative relationship with team atmosphere.

The relationship between strategic alignment of outsourcing and team atmosphere had weak support in this study. An explanation could be the high number of respondents that didn't know the extent of outsourcing on their team. $41 \%$ indicated that they could discern the percentage of outsourced resources. Another possible explanation is that strategic alignment of outsourcing has a relationship with other construct(s) in the study. Strategically aligned outsourcing arrangements tend to support complex projects that may also have more uncertainty. It is possible that the strategic alignment facilitates the positive effect of team atmosphere on team performance, especially in complex projects. We tested for the moderating effects of strategic alignment on the relationship between team atmosphere and team performance and found support for it. The results of this additional analysis have been presented in table 4 .

Also, team performance was regressed with the addition of the strategic alignment of outsourcing and the combined independent variable of team atmosphere and the strategic alignment of outsourcing. Table 4. presents the findings of this test.

Table 4. Results of additional regression analysis for team performance

\begin{tabular}{|l|l|}
\hline Independent variable & \multicolumn{1}{|c|}{ Team atmosphere } \\
\hline Intercept & $1.93659^{* * *}$ \\
\hline Relationship conflict & $-0.1732 * * *$ \\
\hline Task conflict & $0.21979 * *$ \\
\hline Task complexity & $-0.13611^{*}$ \\
\hline Outsourcing & $-0.38725 * *$ \\
\hline Team atmosphere & $0.61953^{* * * *}$ \\
\hline $\begin{array}{l}\text { Outsourcing } * \text { team } \\
\text { atmosphere }\end{array}$ & $0.06905 * *$ \\
\hline R-Square & 0.5961 \\
\hline $\mathrm{F}$ & 32.74 \\
\hline Prob. $(\mathrm{F})$ & $<.0001$ \\
\hline $\mathrm{N}$ & 130 \\
\hline$* \mathrm{p}<0.10 ; * * \mathrm{p}<0.05 ; * * * \mathrm{p}<0.01 ; * * * * \mathrm{p}<0.001$ \\
\hline
\end{tabular}

\section{Conclusion}

This study highlights the importance of having a favorable team atmosphere in improving the performance of outsourcing teams. A favorable team atmosphere is related to having fewer conflicts in the teams. In addition, our study provides weak support for the positive relationship between strategic alignment of outsourcing and team atmosphere. We intend to examine this relationship rigorously in our future studies by employing a better measure for strategic alignment of outsourcing. We conducted additional statistical analysis and found that strategic alignment of outsourcing has a moderating effect on the relationship between team atmosphere and team performance. We intend to investigate this rigorously in our future study.

\section{References}


[1] Algesheimer, R., Dholakia, U.M., and Gurău, C., "Virtual Team Performance in a Highly Competitive Environment", Group \& Organization Management, 36(2), 2011, pp. 161-190.

[2] Ancona, D.G., and Caldwell, D.F., "Demography and Design: Predictors of New Product Team Performance", Organization Science, 3(3), 1992, pp. 321-341.

[3] Aron, R., and Singh, J.V., "Getting Offshoring Right", Harvard Business Review, 83(12), 2005, pp. 135-143, 154.

[4] Bradley, B.H., Postlethwaite, B.E., Klotz, A.C., Hamdani, M.R., and Brown, K.G., "Reaping the Benefits of Task Conflict in Teams: The Critical Role of Team Psychological Safety Climate", Journal of Applied Psychology, 97(1), 2012, pp. 151.

[5] Brannick, M.T., Roach, R.M., and Salas, E., "Understanding Team Performance: A Multimethod Study", Human Performance, 6(4), 1993, pp. 287-308

[6] Chi, S.P., Chang, Y.Y., and Tsou, C.M., "The Effect of Team Characteristics and Communication Environment to the Virtual Team Performance", International Journal of Networking and Virtual Organisations, 10(2), 2012, pp. 137-152.

[7] Crossman, A., and Lee-Kelley, L., "Trust, Commitment and Team Working: The Paradox of Virtual Organizations", Global networks, 4(4), 2004, pp. 375-390.

[8] Daft, R.L., and Macintosh, N.B., "A Tentative Exploration into the Amount and Equivocality of Information Processing in Organizational Work Units", Administrative science quarterly, 1981, pp. 207-224.

[9] De Dreu, C.K., "When Too Little or Too Much Hurts: Evidence for a Curvilinear Relationship between Task Conflict and Innovation in Teams", Journal of management, 32(1), 2006, pp. 83-107.

[10] De Dreu, C.K.W., and Weingart, L.R., "Task Versus Relationship Conflict, Team Performance, and Team Member Satisfaction: A Meta-Analysis", Journal of Applied Psychology, 88(4), 2003, pp. 741-749.

[11] De Wit, F.R., Greer, L.L., and Jehn, K.A., "The Paradox of Intragroup Conflict: A Meta-Analysis", Journal of Applied Psychology, 97(2), 2012, pp. 360.

[12] Edmondson, A., "Psychological Safety and Learning Behavior in Work Teams", Administrative science quarterly, 44(2), 1999, pp. 350-383.

[13] Evan, W.M., "Conflict and Performance in R \& D Organizations", IMR; Industrial Management Review (pre-1986), 7(1), 1965, pp. 35 .

[14] Forza, C., "Survey Research in Operations Management: A Process-Based Perspective", International journal of operations \& production management, 22(2), 2002, pp. 152-194.

[15] Gallenkamp, J.V., Riedl, B.C., Korsgaard, M.A., Picot, A., Welpe, I.M., and Wigand, R.T., "Conflict, Value Diversity, and
Performance in Virtual Teams", Proceedings of the Eighteenth Americas Conference on Information Systems, 2012

[16] Goo, J., Kishore, R., Nam, K., Rao, H.R., and Song, Y., "An Investigation of Factors That Influence the Duration of It Outsourcing Relationships", Decision Support Systems, 42(4), 2007, pp. 2107-2125.

[17] Goodhue, D.L., "Understanding User Evaluations of Information Systems", Management Science, 41(12), 1995, pp. 1827-1844.

[18] Harris, A., Giunipero, L.C., and Hult, G.T.M., "Impact of Organizational and Contract Flexibility on Outsourcing Contracts", Industrial Marketing Management, 27(5), 1998, pp. 373-384.

[19] Hinds, P.J., and Mortensen, M., "Understanding Conflict in Geographically Distributed Teams: The Moderating Effects of Shared Identity, Shared Context, and Spontaneous Communication", Organization Science, 16(3), 2005, pp. 290-307.

[20] Janssen, O., Van De Vliert, E., and Veenstra, C., "How Task and Person Conflict Shape the Role of Positive Interdependence in Management Teams", Journal of management, 25(2), 1999, pp. 117-141.

[21] Jehn, K.A., "A Multimethod Examination of the Benefits and Detriments of Intragroup Conflict", Administrative science quarterly, 40(2), 1995, pp. 256.

[22] Jehn, K.A., "A Qualitative Analysis of Conflict Types and Dimensions in Organizational Groups", Administrative science quarterly, 1997, pp. 530-557.

[23] Jehn, K.A., and Mannix, E.A., "The Dynamic Nature of Conflict: A Longitudinal Study of Intragroup Conflict and Group Performance", Academy of Management Journal, 44(2), 2001, pp. 238-251.

[24] Jehn, K.A., Rispens, S., and Thatcher, S.M., "The Effects of Conflict Asymmetry on Work Group and Individual Outcomes", Academy of Management Journal, 53(3), 2010, pp. 596-616.

[25] Jehn, K.A., Rispens, S., and Thatcher, S.M., "Managing Conflict in Groups and Teams: Conflict About Conflict", Research on Managing Groups and Teams, 15(2012, pp. 133-159.

[26] Johnston, K., and Rosin, K., "Global Virtual Teams: How to Manage Them", Computer and Management (CAMAN), 2011 International Conference on, 2011, pp. 1-4.

[27] Kirkman, B.L., Rosen, B., Tesluk, P.E., and Gibson, C.B., "The Impact of Team Empowerment on Virtual Team Performance: The Moderating Role of Face-to-Face Interaction", Academy of Management Journal, 47(2), 2004, pp. 175-192.

[28] Kishore, R., Rao, H.R., Nam, K., Rajagopalan, S., and Chaudhury, A., "A Relationship Perspective on It Outsourcing", Communications of the ACM, 46(12), 2003, pp. 86-92.

[29] Kostopoulos, K.C., and Bozionelos, N., "Team Exploratory and Exploitative Learning: Psychological Safety, Task Conflict, 
and Team Performance", Group \& Organization Management, 36(3), 2011, pp. 385-415.

[30] Mani, D., Srikanth, K., and Bharadwaj, A., "Efficacy of R\&D Work in Offshore Captive Centers: An Empirical Study of Task Characteristics, Coordination Mechanisms, and Performance", Information Systems Research, 25(4), 2014, pp. 846-864.

[31] Maznevski, M.L., and Chudoba, K.M., "Bridging Space over Time: Global Virtual Team Dynamics and Effectiveness", Organization Science, 11(5), 2000, pp. 473-492.

[32] Mesmer-Magnus, J.R., and Dechurch, L.A., "Information Sharing and Team Performance: A Meta-Analysis", Journal of Applied Psychology, 94(2), 2009, pp. 535.

[33] Moon, J., Swar, B., Chan Choe, Y., Chung, M., and Hyun Jung, G., "Innovation in It Outsourcing Relationships: Where Is the Best Practice of It Outsourcing in the Public Sector?", Innovation: management, policy \& practice, 12(2), 2010, pp. 217 226.

[34] Nam, K., Rajagopalan, S., Raghav Rao, H., and Chaudhury, A., "A Two-Level Investigation of Information Systems Outsourcing", Commun. ACM, 39(7), 1996, pp. 36-44.

[35] Nunnally, J., "Psychometric Methods", New York: McGrawHill, 1978,

[36] Oshri, I., Kotlarsky, J., and Willcocks, L., "Missing Links: Building Critical Social Ties for Global Collaborative Teamwork", Communications of the ACM, 51(4), 2008, pp. 76-81.

[37] Park, J.Y., Im, K.S., and Kim, J.S., "The Role of It Human Capability in the Knowledge Transfer Process in It Outsourcing Context", Information \& Management, 48(1), 2011, pp. 53-61.

[38] Paul, S., and Ray, S., "Cultural Diversity, Perception of Work Atmosphere, and Task Conflict in Collaboration Technology Supported Global Virtual Teams: Findings from a Laboratory Experiment", System Sciences, 2009. HICSS'09. 42nd Hawaii International Conference on, 2009, pp. 1-10.

[39] Paul, S., Seetharaman, P., Samarah, I., and Mykytyn, P., "Understanding Conflict in Virtual Teams: An Experimental Investigation Using Content Analysis", System Sciences, 2005. HICSS'05. Proceedings of the 38th Annual Hawaii International Conference on, 2005, pp. 44a-44a.

[40] Paul, S., Seetharaman, P., Samarah, I., and Mykytyn, P.P., "Impact of Heterogeneity and Collaborative Conflict Management Style on the Performance of Synchronous Global Virtual Teams", Information \& Management, 41(3), 2004, pp. 303-321.

[41] Pazos, P., "Conflict Management and Effectiveness in Virtual Teams", Team Performance Management, 18(7/8), 2012, pp. 401-417.

[42] Perrow, C., "A Framework for the Comparative Analysis of Organizations", American sociological review, 1967, pp. 194-208.
[43] Picazo, C., Gamero, N., Zornoza, A., and Peiró, J.M., "Testing Relations between Group Cohesion and Satisfaction in Project Teams: A Cross-Level and Cross-Lagged Approach", European Journal of Work and Organizational Psychology, 24(2), 2015, pp. 297-307.

[44] Salas, E., Grossman, R., Hughes, A.M., and Coultas, C.W., "Measuring Team Cohesion Observations from the Science", Human Factors: The Journal of the Human Factors and Ergonomics Society, 57(3), 2015, pp. 365-374.

[45] Shaw, J.D., Zhu, J., Duffy, M.K., Scott, K.L., Shih, H.-A., and Susanto, E., "A Contingency Model of Conflict and Team Effectiveness", Journal of Applied Psychology, 96(2), 2011, pp. 391-400.

[46] Simons, T.L., and Peterson, R.S., "Task Conflict and Relationship Conflict in Top Management Teams: The Pivotal Role of Intragroup Trust", Journal of Applied Psychology, 85(1), 2000, pp. 102.

[47] Sleebos, E., Ellemers, N., and De Gilder, D., "Explaining the Motivational Forces of (Dis) Respect: How Self-Focused and Group-Focused Concerns Can Result in the Display of GroupServing Efforts", Gruppendynamik und Organisationsberatung, 38(3), 2007, pp. 327-342.

[48] Søderberg, A.-M., Krishna, S., and Bjørn, P., "Global Software Development: Commitment, Trust and Cultural Sensitivity in Strategic Partnerships", Journal of International Management, 19(4), 2013, pp. 347-361.

[49] Srikanth, K., and Puranam, P., "Integrating Distributed Work: Comparing Task Design, Communication, and Tacit Coordination Mechanisms", Strategic Management Journal, 32(8), 2011, pp. 849-875.

[50] Stewart, G.L., Courtright, S.H., and Barrick, M.R., "PeerBased Control in Self-Managing Teams: Linking Rational and Normative Influence with Individual and Group Performance", Journal of Applied Psychology, 97(2), 2012, pp. 435.

[51] Tushman, M.L., and Nadler, D.A., "Information Processing as an Integrating Concept in Organizational Design", Academy of Management Review, 3(3), 1978, pp. 613-624.

[52] Yang, D.-H., Kim, S., Nam, C., and Min, J.-W., "Developing a Decision Model for Business Process Outsourcing", Computers \& Operations Research, 34(12), 2007, pp. 3769-3778.

[53] Zarraga, C., and Bonache, J., "The Impact of Team Atmosphere on Knowledge Outcomes in Self-Managed Teams", Organization Studies, 26(5), 2005, pp. 661-681. 